\title{
Hydrolithological Investigation for Near-Surface Aquifers Within Lekki Peninsula, Lagos, Southwestern Nigeria
}

\author{
O. G. Bayowa*, T. A. Adagunodo**†, O. A. Olaleye*, A. E. Adeleke*, M. R. Usikalu** and S. A. Akinwumi** \\ *Department of Earth Sciences, Ladoke Akintola University of Technology, P.M.B. 4000, \\ Ogbomoso, Nigeria \\ **Department of Physics, Covenant University, P.M.B. 1023, Ota, Nigeria \\ $†$ Corresponding author: T. A. Adagunodo; theophilus.adagunodo@covenantuniversity.edu.ng
}

Nat. Env. \& Poll. Tech. Website: www.neptjournal.com

Received: 27-05-2019

Accepted: 22-07-2019

Key Words:

Aquifers; Litho-logs;

Vertical electrical sounding

(VES);

Lekki peninsula;

Groundwater

\begin{abstract}
This study is aimed at investigating the near-surface aquifers within Lekki Peninsula, Lagos, Southwestern Nigeria. Thirty-one (31) Vertical Electrical Sounding (VES) data were acquired using the Schlumberger array with current electrode spacing, which varies between 1 and $400 \mathrm{~m}$. The VES data were quantitatively interpreted, and the final layer parameters obtained were used to generate 2D geoelectric sections. Litho-logs acquired within the Lekki Peninsula were used to correlate the geoelectric sections to understand the nature and depth of groundwater contained in each aquiferous zone. The lithologies delineated in the study area include the topsoil (fill and/or sand) with resistivity value, which varies between 39 and $1535 \Omega \mathrm{m}$ as well as layer thickness from 0.5 to $5.5 \mathrm{~m}$; second layer of wet clay/sandy clay (saturated with brackish water) with resistivity value, which varies between5 and $163 \Omega \mathrm{m}$ as well as layer thickness from 1.5 to $10 \mathrm{~m}$; third layer of clayey sand/sand (saturated with freshwater) with resistivity value, which varies between 10 and $898 \Omega \mathrm{m}$ as well as layer thickness value from 5 to $34 \mathrm{~m}$; and fourth layer of clay (saturated with saline water) with resistivity value, which varies between 1 and $9 \Omega \mathrm{m}$. Isolated sand bodies (probably unsaturated zone) with resistivity value, which varies from 648 to $3560 \Omega \mathrm{m}$, were delineated beneath VES stations 24, 25, 29 and 30. The study concludes that the topsoil (sand/fill), unsaturated zone (conglomerate), silty mud layer (brackish/ freshwater saturated), and sand layer (saline water-saturated) constitute the aquifers and water quality within Lekki Peninsular. The inhabitants of the study area are, therefore, advised to avoid absurd usage of water to reduce the pumping rate and intrusion into the saline water formation.
\end{abstract}

\section{INTRODUCTION}

Water is one of the basic needs of life (Anomohanran 2013, Shishaye \& Abdi 2016, Adagunodo et al. 2018a). It is quite abundant on the planet Earth. It is available to man as rain, surface water and groundwater (Adagunodo et al. 2018a), with different uses in domestic, industrial and agricultural settings. However, the availability of potable water with good quality for man's numerous needs is being challenged with pollution and dryness in some locations within Sub Saharan Africa. Therefore, groundwater has been the most preferred resources out of the available sources of water to man. Groundwater is one of the natural resources that are widely distributed in the subsurface, with vital roles in man's life (Kalaivanan et al. 2019). Despite its availability, it is also challenged with pollution (either from geogenic or anthropogenic sources) and inadequate information about the lithologic compositions of the near-surface for groundwater exploitation (Olafisoye et al. 2012, Sunmonu et al. 2012, Adagunodo et al. 2013, Oladejo et al. 2013, Sunmonu et al. 2013, Bayowa et al. 2014a, b, Oladejo et al. 2015, Sunmonu et al. 2015, Sunmonu et al. 2016, Adagunodo 2017a,b, Adagunodo 2018, Adagunodo et al. 2018b, c, Adejumo et al. 2018, Bayowa et al. 2018, Oyeyemi et al. 2018a, b, Sunmonu et al. 2018, Adagunodo et al. 2019a).

Potable water supply in coastal areas of the world has been a major concern due to saltwater intrusion since it constitutes the commonest of all pollutants of freshwater (Demirel 2004 and Batayneh 2006). In Nigeria, coastal communities like Aiyetoro (in Ondo state) and Lekki Pennisula (in Lagos state), are characterized by salty near-surface water, as about $90 \%$ of the boreholes drilled so far in these communities have been reported to yield saline-water and $10 \%$ known of producing freshwater after drilling become salty few months later (Oteri \& Atolagbe 2003). Therefore, understanding the mechanisms of saline-water intrusion is essential for proper management of coastal resources (Ginzburg \& Levanon 1987).

To explore these resources for sustainability of life on earth, various geophysical techniques (such as electrical resistivity, electromagnetic, magnetic, seismic refraction, 
magnetotelluric and gravity) have been adopted successfully, either solely or as integration with other methods (Anomohanran 2013, 2015). The choice of geophysical method to use is a function of the depth of investigation and the budget for the exercise (Todd 2004). Out of these geophysical techniques that have been found useful in groundwater exploration, the electrical resistivity technique (employing the Schlumberger array) has been the most widely adopted (Imam \& Hassan 2019). Its acceptance has been attributed to its simplicity on the field (Sunmonu et al. 2012) and data analysis, which is economical when compared to other geophysical techniques (Anomohanran 2013, Mohamaden \& Ehab 2017, Adagunodo et al. 2018a). The geoelectrical technique had been used to map the near-surface characteristics and assess the seawater intrusion in various coastal environments around the globe (Ebraheem et al. 1997, Batayneh 2006, Bauer et al. 2006, Cimino et al. 2008, Adepelumi \& Olorunfemi 2000, Kalaivanan et al. 2019). The magnitude of saline water intrusion from the coastal environment to the aquifers had been attributed to the rate of groundwater withdrawal and recharge; hydraulic gradient; and geological composition of that environment (Freeze \& Cherry 1979). The present study, therefore, intends to use the geoelectrical technique for hydrolithological investigation of the near-surface aquifers around the Lekki Peninsula in Lagos, Nigeria. The choice for Direct Current (DC) resistivity survey is as a result of its ability to provide a quick synoptic picture of saltwater intrusion in terms of its apparent resistivity contrast of the aquifers.

\section{Location and Geology of the Study Area}

The study area is in the south-eastern part of Lagos, it lies between Latitudes $6^{\circ} 25^{\prime}$ to $6^{\circ} 28^{\prime} \mathrm{N}$ and Longitudes $3^{\circ} 24^{\prime}$ to $3^{\circ} 30^{\prime} \mathrm{E}$ (Fig. 1). It is bounded to the north by Lagos and Lekki lagoons, and to the south by the Atlantic Ocean. The area-Lekki and environs constitute part of the extensive barrier-lagoon complex in the coastal margin of Southwestern Nigeria.

This barrier-lagoon system is composed of five physiographic units which are broadly equivalents to sedimentary sub-environments. The units are beaches and barrier islands, channels and creeks, open lagoons, small deltas built into lagoons and swamps bordering the lagoons. The climate of the study area is tropical wet and dry seasons. A bimodal wet season is experienced in Lagos, with the first regime varying from April to July and the second regime from October to November. Two dry seasons are also experienced annually, with the major dry season varying from February to April and minor dry spell varying from August to September. Monthly temperature varies between $20^{\circ}$ and $37^{\circ} \mathrm{C}$. February to April is the major months with peak records of temperature in the study area. The relative humidity is persistently high and rarely below 70 per cent throughout the year along the Lagos coast.

The regional geology of Nigeria is embedded within the Pan-African mobile belt. This belt is believed to have separated Congo from West Africa Cratons (Adagunodo et al. 2018a, d, e). The separation experienced within this region is as a result of thermotectonic events over the years (Usikalu et al. 2018). The major geological settings in Nigeria are Basement Complex rocks (Adagunodo et al. 2013, 2017a, b, 2018a, 2019b) and Sedimentary Basins (Adagunodo et al. 2018f, g, 2019c). These two geological settings are equally distributed across Nigeria. The study area is underlain by Recent-Oligocene coastal plain sands and alluvium (Benin Formation) of the eastern Dahomey Basin (Fig. 2a). Dahomey six depositional groups are: Abeokuta/ Araromi, Ewekoro, Oshosun, Ilaro, Benin and Alluvium/ Akinbo Formations (Fig. 2b). The general geology, structural settings and stratigraphy of the eastern Dahomey Basin have been discussed in the works of Jones \& Hockey (1964). The coastal plain sands are the youngest sedimentary unit in the eastern Dahomey Basin, and consist of series of poorly sorted sands with lenses of black to greyish clays, pebbly sands and sandy-clays deposited under transitional to continental environments (Jones \& Hockey 1964). Recent alluvium constituting the deposits of major rivers (Ogun, Osun and Yewa) draining the eastern Dahomey Basin has been incorporated as part of this formation (Adagunodo et al. 2019c). The coastal plain sands are the main aquifer in Lagos coastal areas that are exploited through boreholes for domestic and industrial water supply (Longe et al. 1987).

\section{MATERIALS AND METHODS}

Thirty-one Vertical Electrical Survey (VES) stations were occupied with ABEM SAS 1000 Terrameter. The Schlumberger electrode array with current electrode spacing varied between 1 and 400m. The acquired VES data were plotted on bi-log papers, where preliminary partial curve matching analysis was used to produce the parameters of the initial layer (resistivity and thickness of each layer). The final layer's parameters for all the sounding points were obtained usingWinResist1D inversion software. The procedure used in this study for data acquisition, processing and analysis is in line with the geosounding technique for groundwater exploration as documented by Sunmonu et al. (2015). The final interpreted layer parameters were used to generate $2 \mathrm{D}$ geoelectric sections. Litho-logs from two boreholes drilled within the Lekki Peninsula area were also acquired to ascertain the subsurface lithologies. The VES results were correlated with the litho-logs to ascertain general near-surface lithology and the quality of the fluid content within the study area. 


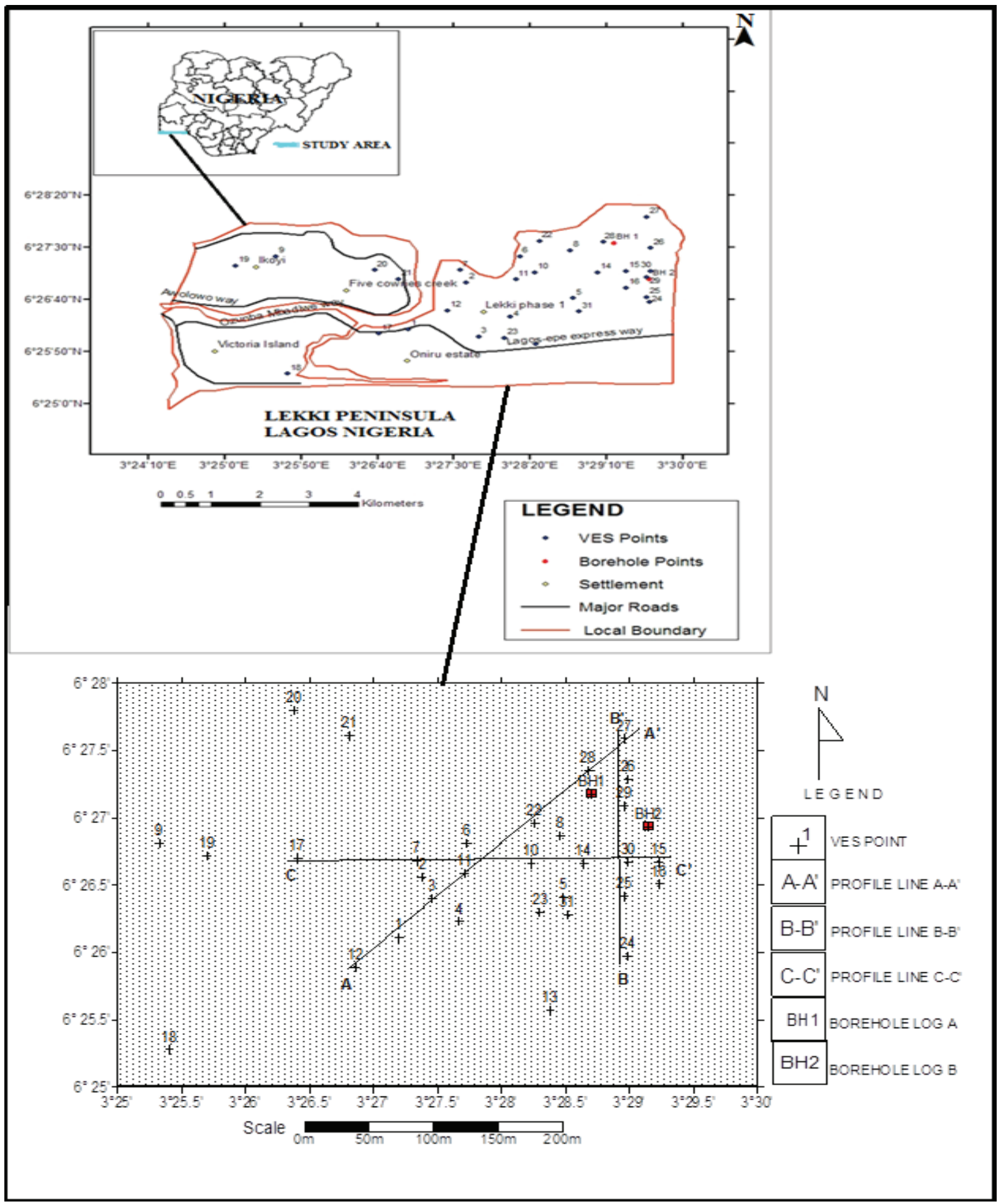

Fig. 1: Base map showing VES points and the borehole locations. 


\section{RESULTS AND DISCUSSION}

The representative iterative curves as obtained in the study area are presented in Fig. 3. The processed VES layers parameters were used to generate the geoelectric sections. The two borehole logs acquired within the study area were interpreted through qualitative and quantitative approach. To understand the subsurface lithologies for sustainable groundwater exploitation in the study area, the geoelectric sections were correlated with borehole logs (litho-logs). The approach used in this study will enable a better understanding of the hydrodynamic equilibrium of the aquifers around the Lekki Peninsula, Lagos.

\section{The Geoelectric Sections}

2D geoelectric sections were generated along the profiles $A-A^{1}, B-B^{1}$ and $C-C^{1}$ (Fig. 1) to show the lateral and vertical distribution of resistivities within the volume of the investigated area. The geoelectric sections span through NE-SW, $\mathrm{N}-\mathrm{S}$ and W-E directions with an approximate length of $600 \mathrm{~m}$, $400 \mathrm{~m}$ and $580 \mathrm{~m}$ respectively (Figs. 4a-c).

The geoelectric section along the profile A-A ${ }^{1}$ (Fig. 4a) relates VES12, 1, 3, 11, 22, 28, and 27. In this section, a maximum of four distinct layers was identified. The topmost layer along this section is characterized by a resistivity value which ranged between $48-1535 \Omega \mathrm{m}$ with a layer thickness ranging from $0.5-5.5 \mathrm{~m}$. This layer generally constitutes the unsaturated zone comprising of sand or fill materials. The second layer beneath this section is a brackish water zone extending southwest of VES12 and dipping beneath VES11 with a later inclination to a more horizontal form beneath VES22, 28 and 27. The lithological composition of this layer constitutes entirely of sand with resistivity value ranging between $14-166 \Omega \mathrm{m}$ and a layer thickness of $4-23 \mathrm{~m}$. The third layer mapped along this section is a zone of silty mud. The hydrodynamics of this layer revealed that brackish water flows at the northeastern flank of the section, while freshwater flows at the southwestern flank. The very steep depression beneath VES11 probably serves as a barrier between the two different water qualities. The depth of the brackish water is between $10-17 \mathrm{~m}$ with a resistivity value between $12-15 \Omega \mathrm{m}$. The freshwater zone thickness ranges between 9-16m with a resistivity value between $75-87 \Omega \mathrm{m}$. The fourth layer delineated beneath this section is the infinite layer which is a saline water zone with resistivity value between $1-8 \Omega \mathrm{m}$ across the section. The thickness of this layer increases along the southwestern trend of the profile (Fig. 4a).

Fig. $4 \mathrm{~b}$ shows the geoelectric section along the profile B-B ${ }^{1}$. This section stretches about $400 \mathrm{~m}$ in a north-south direction spanning through VES24, 25, 30, 29, 26 and 27. The topmost layer which comprises of sands and fill-materials is only about $2 \mathrm{~m}$ deep with a range of resistivity value between 62 and $1254 \Omega \mathrm{m}$. This layer is considered as the unsaturated zone. The second layer beneath is more of sand formation with differing water quality. At VES24 and 25, it is probably saline water saturated with resistivity value between 2 and $7 \Omega \mathrm{m}$, while brackish water is experienced towards the eastern flank of this layer. The zone has a resis-

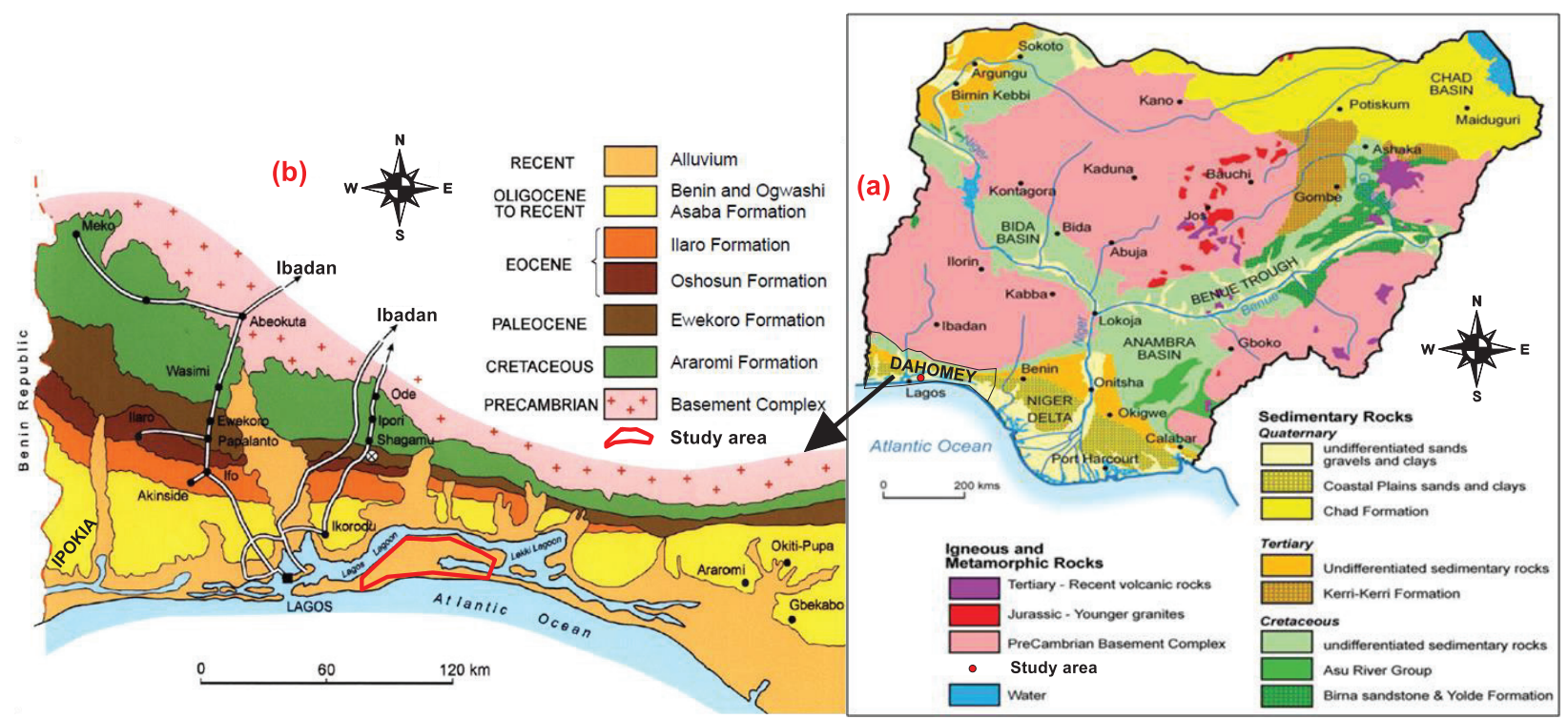

Fig. 2: Geological maps of (a) Nigeria (b) Dahomey Basin revealing the study area [modified from Adagunodo et al. (2018f, 2019c)]. 

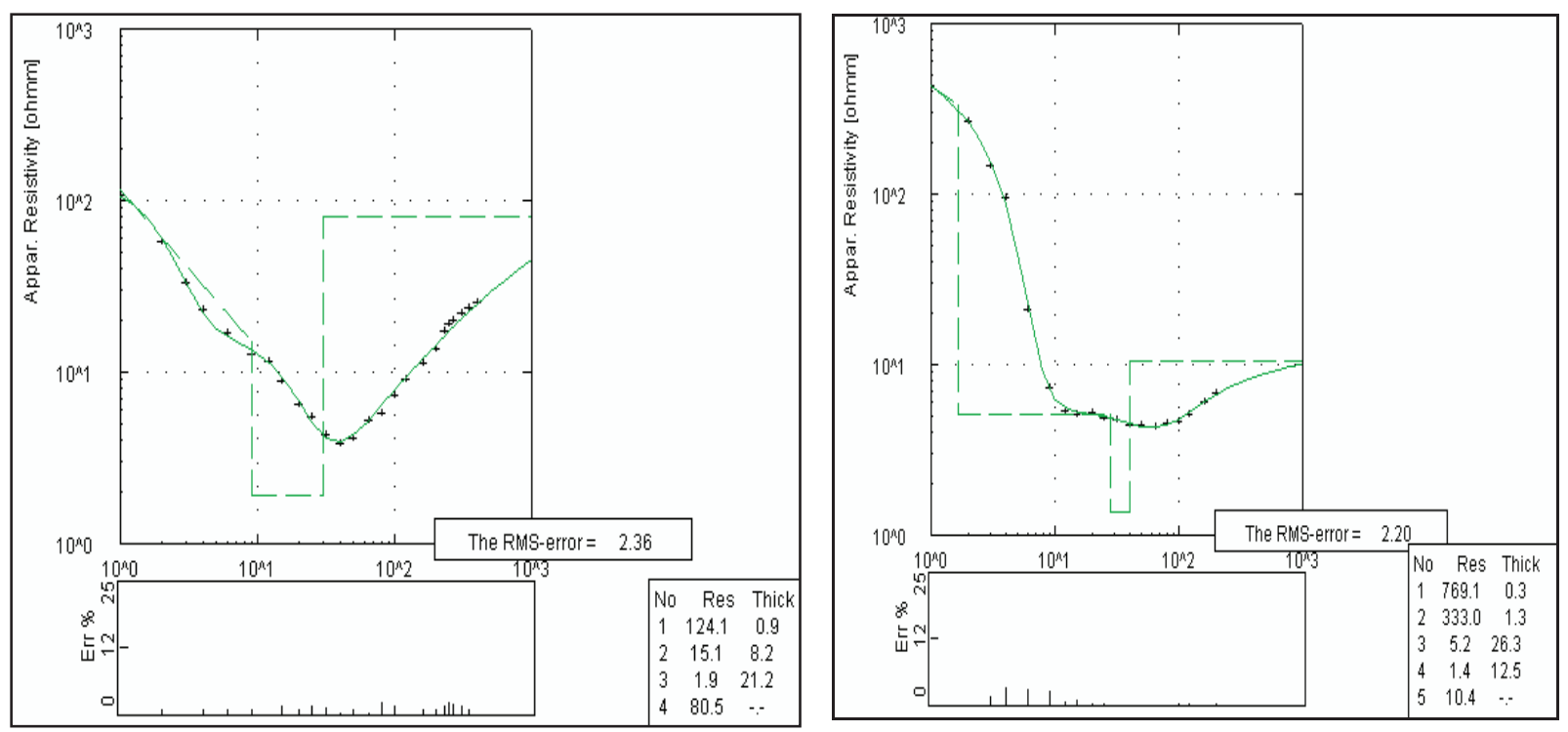

Fig. 3: Selected curve types as obtained in the study area (a) QH curve type (b) QQH curve type.

tivity value between 28 and $74 \Omega \mathrm{m}$. This layer has a thickness range between $2-8 \mathrm{~m}$ and it is directly overlying a silty mud formation with intercalations of conglomerates. This zone could be interpreted as a freshwater aquifer zone, which flows across this profile. The depth range of this aquifer is between $11-42 \mathrm{~m}$, with resistivity value between $74-260 \Omega \mathrm{m}$. However, conglomerates with resistivity varying between 648 and $3560 \Omega \mathrm{m}$ were encountered beneath VES stations 24, 25, 29 and 30 within this layer. The fourth layer in this profile resembles the infinite layer of profile $\mathrm{A}-\mathrm{A}^{1}$.
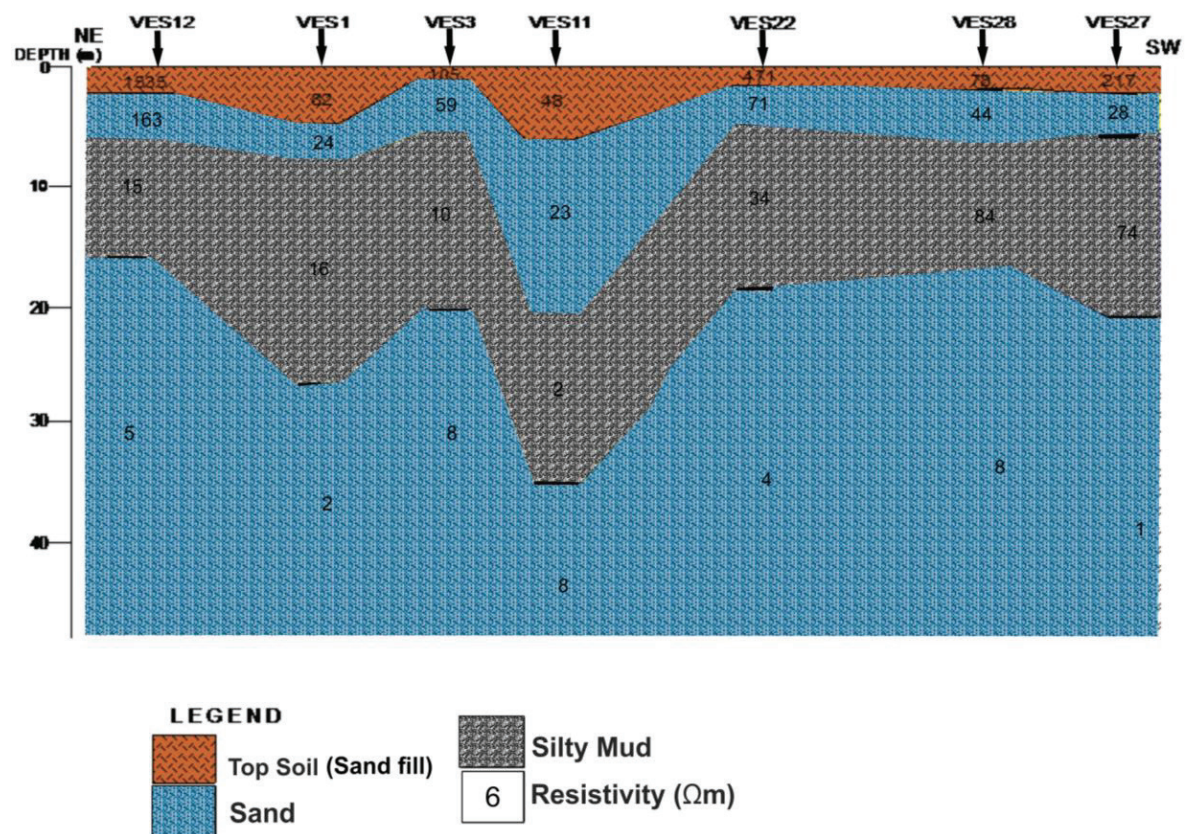

Fig. 4a: Geoelectric section along profile $\mathrm{A}-\mathrm{A}^{1}$. 


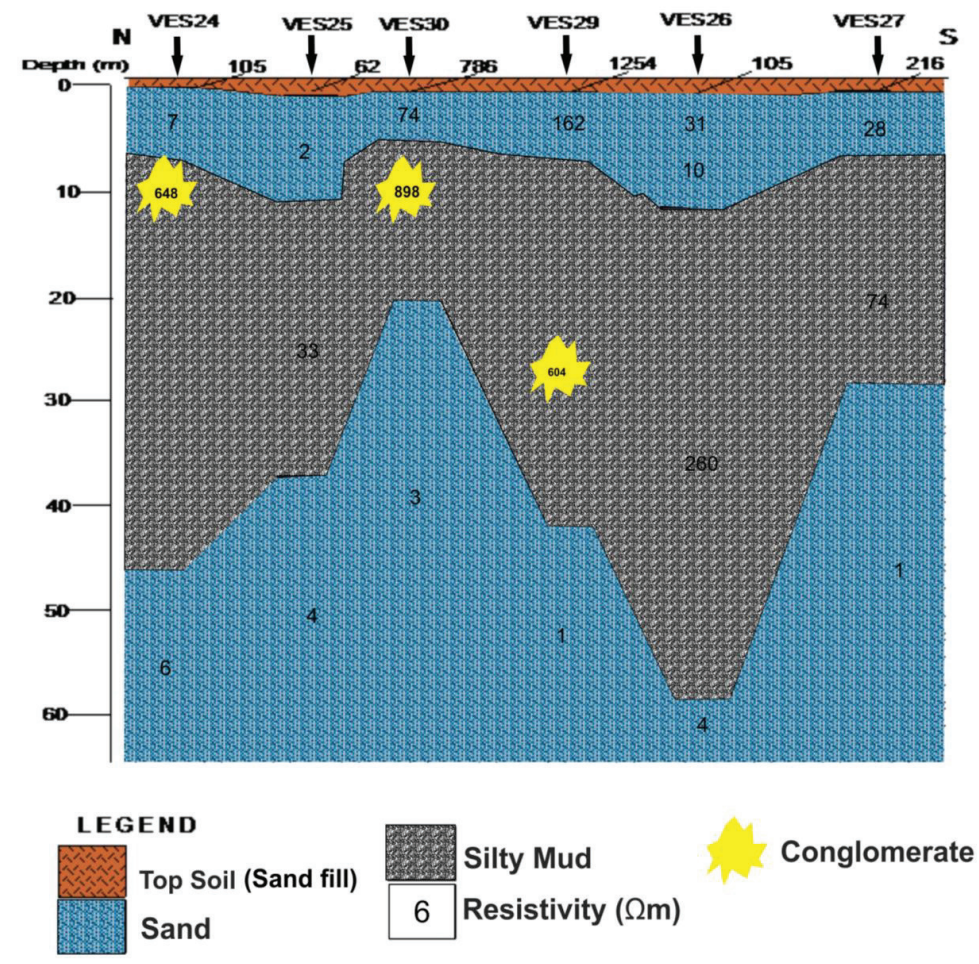

Fig. 4b: Geoelectric section along profile $B-B^{1}$.

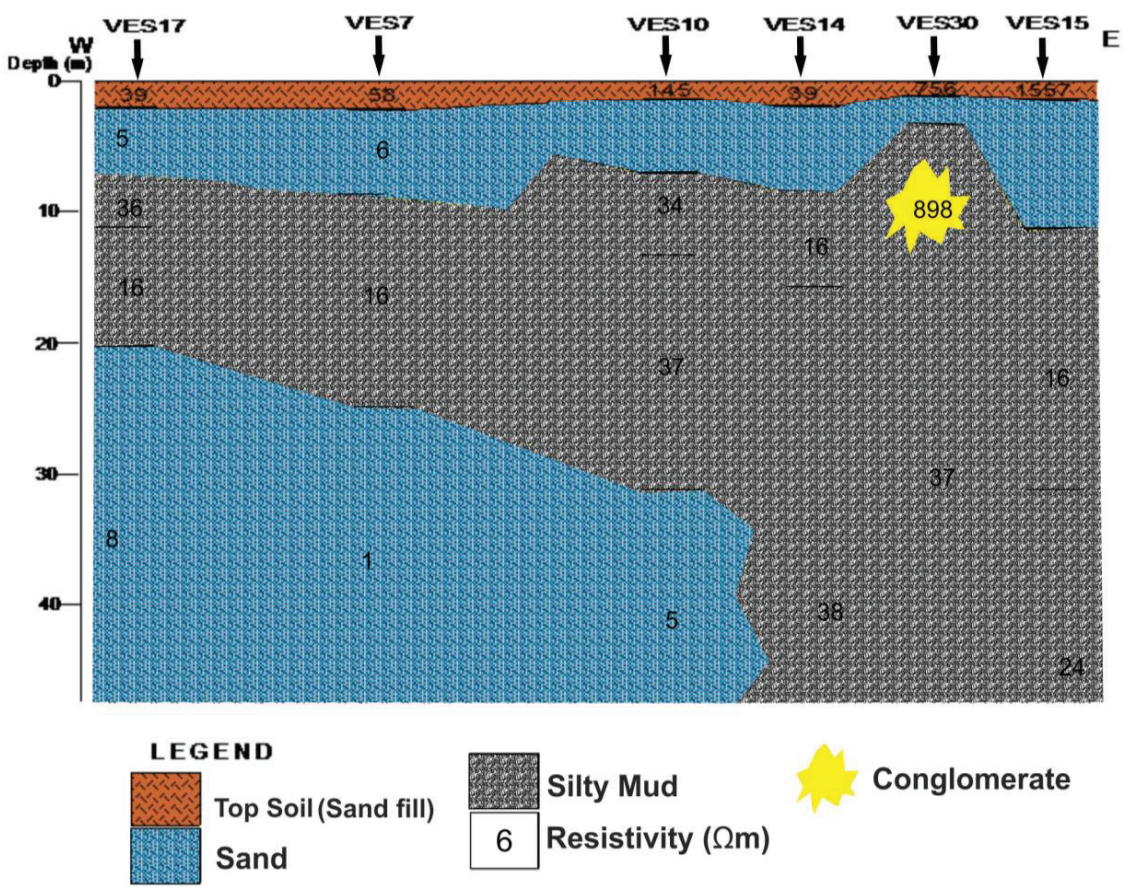

Fig. 4c: Geoelectric section along profile $\mathrm{C}-\mathrm{C}^{1}$. 
The geoelectric section along the profile $\mathrm{C}-\mathrm{C}^{1}$ (Fig. 4c) covers about $580 \mathrm{~m}$ in a west-east direction. This section relates VES17, 7, 10, 14, 30 and 15, which reveals a maximum of four (4) layer sequences. The resistivity value of the first layer ranges between 39 and $780 \Omega \mathrm{m}$ with the thickness of $0.5-2 \mathrm{~m}$. The second layer is interpreted as sand formation, with different hydrodynamic forces. At VES 17 and 7, the water in this zone is probably saline, while beneath VES 10, 14,30 and 15 , the water in this zone could be brackish. Resistivity value along this layer varies between 5 and $81 \Omega \mathrm{m}$, with layer thickness of 3 and $10 \mathrm{~m}$. The third layer is interpreted as a silty mud zone with isolated conglomerate towards the eastern flank of the profile. This layer could be residing zone for brackish water, with a resistivity value between 16 and $38 \Omega \mathrm{m}$. The fourth layer is an infinite layer which could be interpreted as sand formation that is saline water-saturated, with varying resistivity between 1 and $10 \Omega \mathrm{m}$. The fourth layer in the three (3) profiles share the same characteristics, which reveal the mean depth at which saline water could intrude to the aquifer in the Lekki Peninsula.

\section{Borehole Logs}

Quantitative and qualitative evaluation of the litho-logs acquired revealed the presence of saline, brackish and freshwater saturated units within the borehole sections (Figs. 5a-b). The lithology of the borehole consists entirely of sand and silty mud, which are typical of the Benin Formation. The borehole $\log 1$ revealed a 5-layer lithology, which varied vertically downward as sand, silty mud, sand, silty mud and sand, with a maximum depth of about $65 \mathrm{~m}$. Borehole $\log 2$ revealed a 4-layer lithology, which varied vertically downward as sand, silty mud, sand and silty mud, with a maximum depth of about $70 \mathrm{~m}$. The zones of freshwater on the two logs correspond to the second layer silty mud, which varied from 18 to $35 \mathrm{~m}$ in $\log 1$ (Fig. 5a) and 22 to $38 \mathrm{~m}$ in $\log 2$ (Fig. 5b), respectively. As revealed on the logs, the third layer which is composed of sand formation corresponds to the infinite layer (fourth layer) on the geoelectric section, which houses the saline water at this zone.

\section{Integration of VES and Borehole Litho-Logs Results}

Figs. 6a-b show the correlation between the VES points and borehole logs. The topmost layer in Fig. 6a has a thickness between 1.2 and $3 \mathrm{~m}$ and varies in resistivity between $79 \Omega \mathrm{m}$ at VES 28 and $478 \Omega \mathrm{m}$ at VES 22. This layer is underlain by sand formation, with depth varying between 3 and $7 \mathrm{~m}$. The third layer correlated with $\log \mathrm{A}$ is a silty mud formation, with depth varying between 16 and $20 \mathrm{~m}$. The resistivity of this layer varied between 44 and $86 \Omega \mathrm{m}$. The range of resistivity value in this layer is an indication of the water saturation (brackish water). The fourth layer correlated is a sand formation, with very low resistivity value of $2-8 \Omega \mathrm{m}$. This is an indication of the layer's salinity (that is, saline water formation). Fig. $6 \mathrm{~b}$ shows log suit B correlation with

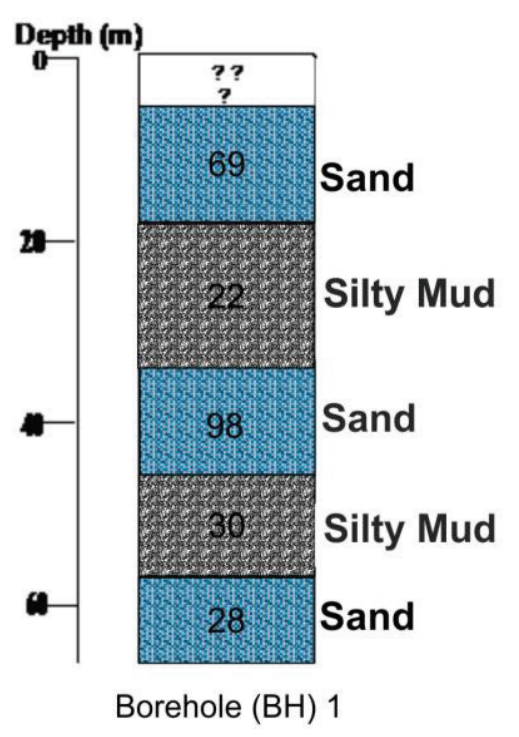

36 Resistivity $(\Omega \mathrm{m})$

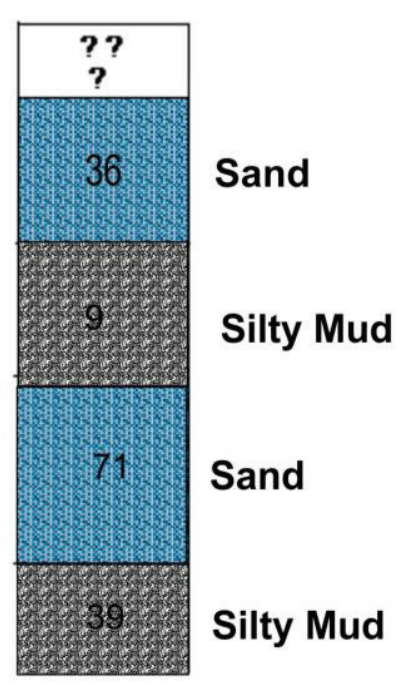

Borehole $(\mathrm{BH}) 2$

Fig. 5: Borehole Litho logs obtained around Lekki Peninsular (a) Log suit A (b) Log suit B. 

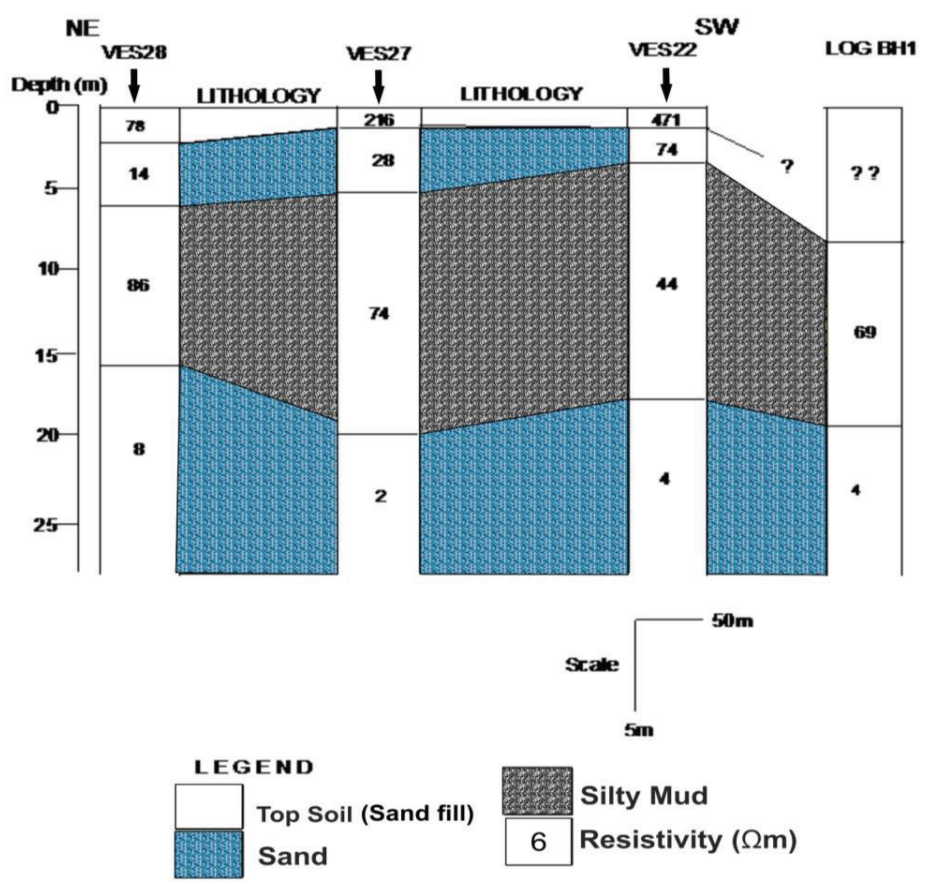

Fig. 6a: Correlation of VES stations with borehole $\log 1$.
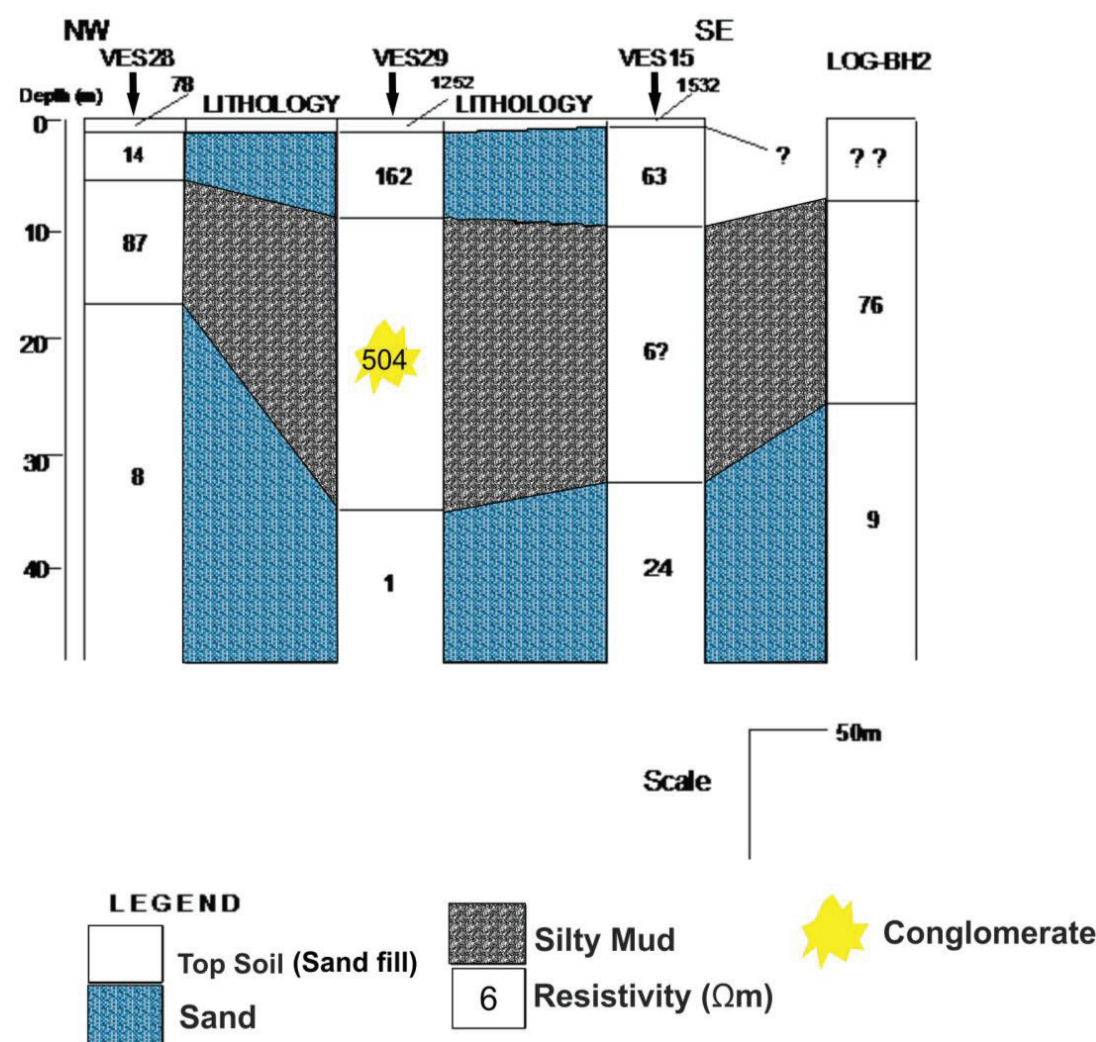

Fig. 6b: Correlation of VES stations with borehole $\log 2$. 
VES points 28, 29 and 15. The topmost layer extends to a depth of $1.5 \mathrm{~m}$ at VES point 28 and thins in the south-east direction towards VES point 15. This layer is characterized by resistivity values between 78 and $1532 \Omega \mathrm{m}$. This layer is underlain by sand formation with varying depths between 5 and $9 \mathrm{~m}$ as well as resistivity value between 14 and $162 \Omega \mathrm{m}$. The third layer correlated with the log is silty mud formation with varying depths between 17 and $35 \mathrm{~m}$. The resistivity value in this layer is indicative of freshwater saturated zone. This third layer is underlain by saline water zone with resistivity values ranging between 1 and $9 \Omega \mathrm{m}$.

\section{CONCLUSIONS}

Hydrolithological investigation of Lekki peninsula area of Lagos, Southwestern Nigeria has been carried out using the surface and borehole litho-logs. The dominant trend of decreasing resistivity value with depth in part of the investigated area indicates an increase in salinity with depth (seawater/lagoon intrusion). Differences in resistivity value within the surveyed area are associated with the various lithologic types, water saturation and groundwater type (saline or freshwater). Distinct zone of saline water intrusion into the freshwater aquifer has been delineated in the near-surface based on resistivity variations. The prominent factor responsible for saline water intrusion observed in the study area is the excessive pumping of groundwater which results to the disturbance in the hydrodynamic equilibrium of the aquifer and the reduction of groundwater gradient allowing saline water to displace freshwater in the aquifer. Along the studied profiles, the upper interface between fresh, brackish and saline waters was encountered at the top $60 \mathrm{~m}$ as inferred from the borehole log suits. In conclusion, the study area is characterized by the topsoil (sand/fill), conglomerate layer (unsaturated zone), silty mud layer (brackish/freshwater saturated), and sand layer (saline water-saturated). It is recommended that the people living/working within the study area should avoid excessive wastage of water to reduce the pumping rate and intrusion into the saline water formation.

\section{ACKNOWLEDGEMENTS}

The authors are indebted to Mr. Abideen of ROWDOT Geological Service for his immense contribution to the success of this study. Our sincere and endless thanks also go to the C.E.O of Groundwater and Geophysical Service Limited and Mr. Jude of Eauxwell Nigeria Limited. We also express our profound gratitude and appreciation to all our colleagues who made the fieldwork realistic. Finally, we acknowledge the support received from Covenant University.

\section{REFERENCES}

Adagunodo, T.A., Sunmonu, L.A., Ojoawo, A., Oladejo, O.P. and Olafisoye, E.R. 2013. The hydro geophysical investigation of Oyo state industrial estate Ogbomosho, Southwestern Nigeria using vertical electrical soundings. Research Journal of Applied Sciences, Engineering and Technology, 5(5): 1816-1829.

Adagunodo, T.A. 2017a. Groundwater pollution and control: An overview. In: Anna L. Powell (ed.) Groundwater Contamination: Performance, Limitations and Impacts, 1-135. ISBN: 978-1-153611-017-3; 978-153611-003-6, Nova Science Publishers, Inc. pp. 1-12.

Adagunodo T.A. 2017b. Groundwater contamination: performance, effects, limitations and control. In: Anna L. Powell (ed.) Groundwater Contamination: Performance, Limitations and Impacts, 1-135. ISBN: 978-1-153611-017-3; 978-1-53611-003-6, Nova Science Publishers, Inc. Pp. 33-64.

Adagunodo, T.A., Adeniji, A.A., Erinle, A.V., Akinwumi, S.A., Adewoyin, O.O., Joel, E.S. and Kayode, O.T. 2017a. Geophysical Investigation into the integrity of a reclaimed open dumpsite for civil engineering purpose. Interciencia Journal, 42(11): 324-339.

Adagunodo, T.A., Sunmonu, L.A., Adabanija, M.A., Suleiman, E.A. and Odetunmibi, O.A. 2017b. Geoexploration of radioelement's datasets in a flood plain of crystalline bedrock. Data in Brief, 15C: 809-820.

Adagunodo, T.A. 2018. Simple approach to groundwater study for domestic uses in rural area. Journal of Fundamental and Applied Sciences, 10(3): 129-143.

Adagunodo, T.A., Akinloye, M.K., Sunmonu, L.A., Aizebeokhai, A.P., Oyeyemi, K.D. and Abodunrin, F.O. 2018a. Groundwater exploration in Aaba residential area of Akure, Nigeria. Frontiers in Earth Science, 6: 66.

Adagunodo, T.A., Sunmonu, L.A., Oladejo, O.P., Hammed, O.S., Oyeyemi, K.D. and Kayode, O.T. 2018b. Site characterization of Ayetoro housing scheme, Oyo, Nigeria. IOP Conference Series: Earth and Environmental Science, 173: 012031 .

Adagunodo, T.A., Sunmonu, L.A., Erinle, A.V., Adabanija, M.A., Oyeyemi, K.D. and Kayode, O.T. 2018c. Investigation into the types of fractures and viable depth to substratum of a housing estate using geophysical techniques. IOP Conference Series: Earth and Environmental Science, 173: 012030.

Adagunodo, T.A., Lüning, S., Adeleke, A.M., Omidiora, J.O., Aizebeokhai, A.P., Oyeyemi, K.D. and Hammed, O.S. 2018d. Evaluation of $0 \leq \mathrm{M} \leq$ 8 earthquake data sets in African Asian region during 1966-2015. Data in Brief, 17C: 588-603.

Adagunodo, T.A., Sunmonu, L.A. and Emetere, M.E. 2018e. Heavy metals' data in soils for agricultural activities. Data in Brief, 18C: 1847-1855.

Adagunodo, T.A., George, A.I., Ojoawo, I.A., Ojesanmi, K. and Ravisankar, R. 2018f. Radioactivity and radiological hazards from a kaolin mining field in Ifonyintedo, Nigeria. MethodsX, 5C: 362-374.

Adagunodo, T.A., Hammed, O.S., Usikalu, M.R., Ayara, W.A. and Ravisankar, R. 2018g. Data on the radiometric survey over a kaolinitic terrain in Dahomey Basin, Nigeria. Data in Brief, 18C: 814-822.

Adagunodo, T.A., Adejumo, R.O. and Olanrewaju, A.M. 2019a. Geochemical classification of groundwater system in a rural area of Nigeria. In: Chaminé H., Barbieri M., Kisi O., Chen M., Merkel B. (eds) Advances in Sustainable and Environmental Hydrology, Hydrogeology, Hydrochemistry and Water Resources. Advances in Science, Technology \& Innovation (IEREK Interdisciplinary Series for Sustainable Development). Springer, Cham.

Adagunodo, T.A., Sunmonu, L.A., Adabanija, M.A., Omeje, M., Odetunmibi, O.A. and Ijeh, V. 2019b. Statistical assessment of radiation exposure risks of farmers in Odo Oba, southwestern Nigeria. Bulletin of the Mineral Research and Exploration, 159: 199-215.

Adagunodo, T.A., Bayowa, O.G., Usikalu, M.R. and Ojoawo, A.I. 2019c. 
Radiogenic heat production in the coastal plain sands of Ipokia, Dahomey Basin, Nigeria. MethodsX, 6C: 1608-1616.

Adejumo, R.O., Adagunodo, T.A., Bility, H., Lukman, A.F. and Isibor, P.O. 2018. Physicochemical constituents of groundwater and its quality in crystalline Bedrock, Nigeria. International Journal of Civil Engineering and Technology, 9(8): 887-903.

Adepelumi, A.A. and Olorunfemi, M.O. 2000. Engineering geological and geophysical investigation of the reclaimed Lekki Peninsula, Lagos, Southwestern Nigeria. Bull. Eng. Geol. Environ., 58: 125-132.

Anomohanran, O. 2013. Geophysical investigation of groundwater potential in Ukeleghe, Nigeria. Journal of Applied Sciences, 13(1): 119-125.

Anomohanran, O. 2015. Hydrogeophysical and hydrogeological investigations of groundwater resources in Delta Central, Nigeria. Journal of Taibah University for Science, 9: 57-68.

Batayneh, A.T. 2006. Use of electrical resistivity methods for detecting subsurface fresh and saline water and delineating their interfacial configuration: A case study of the eastern Dead Sea coastal aquifers. Jordan Hydrogeology J., 14(1): 277-1283.

Bauer, P., Supper, R., Zimmermann, S. and Kinzelbach, W. 2006. Geoelectrical imaging of groundwater salinization in the Okavango Delta, Botswana. Journal of Applied Geophysics, 60: 126-141.

Bayowa, O.G., Olorunfemi, M.O., Akinluyi, F.O. and Ademilua, O.L. 2014a. A preliminary assessment of the groundwater potential of Ekiti State, Southwestern Nigeria, using terrain and satellite imagery analyses. Journal of Environmental and Earth Science, 4(18): 33-42.

Bayowa, O.G., Olorunfemi, M.O., Akinluyi, F.O. and Ademilua, O.L. 2014b. Integration of hydrogeophysical and remote sensing data in the assessment of groundwater potential of the basement complex terrain of Ekiti State, Southwestern Nigeria. Ife Journal of Science, 16(3): 353-363.

Bayowa, O.G., Fashola, D.K., Adegoke, A.B., Agesin, A.A. and Oyeniyi, S.A. 2018. Geophysical investigation for groundwater potential around Ladoke Akintola University of Technology campus, Ogbomoso, Southwestern Nigeria. Journal of Earth Science and Climatic Change, 9(8): 2-10.

Cimino, A., Cosentino, C., Oieni, A. and Tranchina, L. 2008. A geophysical and geochemical approach for seawater intrusion assessment in the Acquedolci coastal aquifer (Northern Sicily). Environmental Geology, 55: $1473-1482$

Demirel, Z. 2004. The history and evaluation of saltwater intrusion into a coastal aquifer in Mersin, Turkey. J. Environ. Manage., 70: 275-282.

Ebraheem, A.A.M., Senosy, M.M. and Dahab, K.A 1997. Geoelectrical and hydrogeochemical studies for delineating ground-water contamination due to salt-water intrusion in the Northern part of the Nile Delta, Egypt. Ground Water, 35: 216-222.

Freeze, A.R. and Cherry, J. A. 1979. Groundwater. Prentice Hall Inc., New Jersey.

Ginzburg, A. and Levanon, A. 1976. Determination of a saltwater interface by electric resistivity depth soundings. Hydrogeological Sciences, 21: 561-568.

Imam, A. and Hassan, Q. 2019. Geophysical investigation for groundwater potential of an area in Delhi NCR. Jordan Journal of Civil Engineering, 13(2): 361-376.

Jones, H.A. and Hockey R.D. 1964. Geology of parts of Southwestern Nigeria. Bulletin Geological Survey of Nigeria, 31: 56-77.

Kalaivanan, K., Gurugnanam, B., Suresh, M., Kom, K.P. and Kumaravel, S. 2019. Geoelectrical resistivity investigation for hydrogeology conditions and groundwater potential zone mapping of Kodavanar Sub-basin, southern India. Sustainable Water Resources Management, 1-21.

Longe, E.O., Malomo, S. and Olorunniwo, M.A. 1987. Hydrogeology of Lagos Metropolis. Africa Journal of Earth Sciences, 6(2): 163-174.
Mohamaden, M.I.I. and Ehab, D. 2017. Application of electrical resistivity for groundwater exploration in Wadi Rahaba, Shalateen, Egypt. NRIAG Journal of Astronomy and Geophysics, 6: 201-209.

Olafisoye, E.R., Sunmonu, L.A., Ojoawo, A., Adagunodo, T.A. and Oladejo, O.P. 2012. Application of very low frequency electromagnetic and hydro-physicochemical methods in the investigation of groundwater contamination at Aarada waste disposal site, Ogbomoso, Southwestern Nigeria. Australian Journal of Basic and Applied Sciences, 6(8): 401-409.

Oladejo, O.P., Sunmonu, L.A., Ojoawo, A., Adagunodo, T.A. and Olafisoye, E.R. 2013. Geophysical investigation for groundwater development at Oyo State Housing Estate Ogbomosho, Southwestern Nigeria. Research Journal of Applied Sciences, Engineering and Technology, 5(5): 1811-1815.

Oladejo, O.P., Sunmonu, L.A. and Adagunodo, T.A. 2015. Groundwater prospect in a typical Precambrian basement complex using KarousHjelt and Fraser Filtering Techniques. Journal of Industrial Engineering Research, 1(4): 40-49.

Oteri, A.U. and Atolagbe, F.P. 2003. Saltwater intrusion into coastal aquifers in Nigeria the second international conference on saltwater intrusion and coastal aquifers-Monitoring, Modeling, and Management. Mérida, Yucatán, México, March 30-April 2, 2003.

Oyeyemi, K.D., Aizebeokhai, A.P., Ndambuki, J.M., Sanuade, O.A., Olofinnade, O.M., Adagunodo, T.A., Olaojo, A.A. and Adeyemi, G.A. 2018a. Estimation of aquifer hydraulic parameters from surficial geophysical methods: A case study of Ota, Southwestern Nigeria. IOP Conference Series: Earth and Environmental Science, 173: 012028.

Oyeyemi, K.D., Aizebeokhai, A.P., Sanuade, O.A., Ndambuki, J.M., Olofinnade, O.M., Olaojo, A.A. and Adagunodo, T.A. 2018b. The use of geological-based geophysical surveys for groundwater distribution in crystalline basement terrain, SW Nigeria. IOP Conference Series: Earth and Environmental Science, 173: 012029.

Shishaye, H.A. and Abdi, S. 2016. Groundwater exploration for water well site locations using geophysical survey methods. Hydrology Current Research, 7(1): 1-7.

Sunmonu, L.A., Adagunodo, T.A., Olafisoye, E.R. and Oladejo, O.P. 2012. The groundwater potential evaluation at industrial estate Ogbomoso Southwestern Nigeria. RMZ-Materials and Geoenvironment, 59(4): 363-390.

Sunmonu, L.A., Olafisoye, E.R., Adagunodo, T.A. and Alagbe, O.A. 2013. Geophysical and hydro-physicochemical evaluation of hand-dug wells near a dumpsite in Oyo State, Nigeria. Archives of Applied Science Research, 5(6): 29-40.

Sunmonu, L.A., Adagunodo, T.A., Adeniji, A.A., Oladejo, O.P. and Alagbe, O.A. 2015. Geoelectric delineation of aquifer pattern in crystalline bedrock. Open Transactions on Geosciences, 2(1): 1-16.

Sunmonu, L.A., Adagunodo, T.A., Bayowa, O.G. and Erinle, A.V. 2016. Geophysical mapping of the proposed Osun State housing estate, Olupona for subsurface competence and groundwater potential. Journal of Basic and Applied Research, 2(2): 27-47.

Sunmonu, L.A., Adagunodo, T.A., Adeniji, A.A. and Ajani, O.O. 2018. Geoimaging of subsurface fabric in Awgbagba, Southwestern Nigeria using geomagnetic and geoelectrical techniques. Malaysian Journal of Fundamental and Applied Sciences, 14(2): 312-324.

Todd, D.K. 2004. Groundwater Hydrology. $2^{\text {nd }}$ Edition, John Wiley and Sons, New York.

Usikalu, M.R., Oderinde, A., Adagunodo, T.A. and Akinpelu, A. 2018. Radioactivity concentration and dose assessment of soil samples in cement factory and environs in Ogun State, Nigeria. International Journal of Civil Engineering and Technology, 9(9): 1047-1059. 